\title{
Characterization of chromium (III) removal from aqueous solutions by an immature coal (leonardite). Toward a better understanding of the phenomena involved
}

\begin{abstract}
Removal of chromium (III) from aqueous solutions by leonardite (a low-cost adsorbent) was studied in a series of batch experiments. Stabilization of the adsorbent material with alginate beads was also investigated. The extent of adsorption was evaluated as a function of the solution $\mathrm{pH}$, contact time, and the adsorbate concentration. Cr(III) removal was $\mathrm{pH}$ dependent, reaching a maximum at a $\mathrm{pH}$ range of $4-5$. Kinetic studies allowed gives relevant information regarding mass transfer processes involved during the sorption process. Equilibrium data fitted well to both the Langmuir and Freundlich isotherm models and the maximum adsorption capacity turned out to be $75.2 \mathrm{mg} \mathrm{Cr}$ (III) $\mathrm{g}^{-1}$. Encapsulation of leonardite in alginate beads resulted in a slightly lower adsorption capacity.
\end{abstract}

\section{Keywords}

Adsorption Leonardite Chromium (III) Kinetics Isotherm

\section{Introduction}

Chromium is a common pollutant in wastewater resulting from numerous industrial activities such as the preservation of wood, textile dying, leather tanning, electroplating, and metal finishing, mining, cement, and paint industries. Due to the high toxicity of some chromium species, this metal is included in the priority substances list of the European Union (Directive 2008/105/EC). Chromium exists in two oxidation states as Cr(III) and $\mathrm{Cr}(\mathrm{VI})$. Hexavalent chromium is 500 times more toxic than the trivalent form. Moreover, $\mathrm{Cr}$ (III) may be oxidized into $\mathrm{Cr}$ (VI) easily by certain circumstances such as $\mathrm{pH}$ changes and redox potential conditions (Fendorf 1995). Accordingly, wastewaters containing chromium must be treated to reach allowable limits before being discharged into the environment. Conventional methods to remove $\mathrm{Cr}(\mathrm{VI})$ consist, basically, of reducing $\mathrm{Cr}(\mathrm{VI})$ into $\mathrm{Cr}$ (III) and then, eliminating Cr(III) by different techniques. The methods utilized to remove $\mathrm{Cr}$ (III) from industrial wastewaters include: chemical precipitation (Esmaeili et al. 2005), activated carbon adsorption (Lalvani et al. 1998; Di Natale et al. 2007), electrochemical precipitation (Rana et al. 2004; Mouedhen et al. 2009; Vasudevan et al. 2010), ion exchange (Liguori et al. 2006; Rengaraj et al. 2001) and reverse osmosis (Das et al. 2006; Mousavi et al. 2009), among others. The aforesaid methods have many disadvantages like incomplete metal removal, the use of high amounts of reagents, high energy 
requirements and the generation of toxic sludge that needs again safe disposal in further steps. Recently, the use of low-cost sorbents has been investigated as an alternative for current costly methods to remove chromium from aqueous solutions. Natural materials or waste products from certain industries with high sorption capacity for heavy metals can be obtained, and disposed with little cost. A wide variety of materials has been tested as chromium adsorbents and some of them have proved to be suitable for this purpose (Mohan and Pittman 2006). Modification of the superficial properties of these low-cost adsorbents can also improve their stability or/and their effectiveness. Thereby, encapsulation of these materials in a polymeric matrix is a promising technique (Lazaridis and Charalambous 2005; Escudero et al. 2006; Fiol et

al. 2004, 2008). Among low-cost materials, immature coals such as leonardite have already demonstrated their ability to adsorb efficiently pollutants of different nature. The physical and the chemical properties of leonardite make this material suitable for both, organic micropollutants (Zeledón et al. 2007) and heavy metals removal in aqueous solutions (Solé et al. 2003; Zeledón et al. 2005; Lao et al. 2005). This low-rank coal is abundant and has a low cost compared to other substrates as activated carbon or zeolites (Mohan and Pittman 2006).

The aim of this study is to evaluate the feasibility of chromium removal by leonardite. For this purpose, the adsorption of chromium (III) onto leonardite was tested in a series of batch experiments. The effects of the solution $\mathrm{pH}$, the contact time and the chromium concentration were accurately investigated. Several kinetic modeling approaches are also presented for a better understanding of the mass transfer processes involved. Furthermore, in order to facilitate its application, the raw material was immobilized into calcium alginate beads.

\section{Materials and methods}

\section{Adsorbent}

The leonardite used as adsorbent in this study was supplied by Sociedad Española de Productos Húmicos, S.A. (SEPHU®, Zaragoza, Spain). The adsorbent was sieved to a grain size between 0.09 and $0.2 \mathrm{~mm}$. Some of its physical and chemical characteristics are shown in Table 1 . Elemental composition (carbon, hydrogen and nitrogen) was obtained by a Fisons (model 1106) elemental analyzer and the sulfur content using a Fisons 1108 equipment. The oxygen content was estimated by difference. The determination of humic acids percentage was carried out according to a methodology described elsewhere (González et al. 1992). A Micrometrics ASAP 2000 surface analyzer was used for surface area (BET) determination. Moisture content, density, cationic exchange capacity (CEC), and functional acid groups were determined according to Tan (1996).

Table 1

Physicochemical properties of leonardite used in this study 


\begin{tabular}{|l|l|}
\hline $\mathrm{C}(\%)$ & 55.2 \\
\hline $\mathrm{H}(\%)$ & 3.4 \\
\hline $\mathrm{N}(\%)$ & 0.8 \\
\hline $\mathrm{O}(\%)$ & 38.1 \\
\hline $\mathrm{S}(\%)$ & 2.4 \\
\hline BET area $\left(\mathrm{m}^{2} \mathrm{~g}^{-1}\right)$ & 19.9 \\
\hline Moisture content (\%) & 30 \\
\hline Density (g mL-1) & 1.67 \\
\hline CEC (meq g $\left.{ }^{-1}\right)$ & 2.87 \\
\hline Single bond COOH groups (meq $\left.\mathrm{g}^{-1}\right)$ & 3.12 \\
\hline Single bond $\mathrm{OH}$ groups (meq g-1) & 2.07 \\
\hline
\end{tabular}

\section{Chromium stock solution}

$\mathrm{Cr}(\mathrm{III})$ stock solution was prepared by dissolving a known quantity of $\mathrm{Cr}\left(\mathrm{NO}_{3}\right)_{3} \cdot 9 \mathrm{H}_{2} \mathrm{O}$ (Scharlau ${ }^{\circledR}$, Barcelona, Spain) in Milli-Q ${ }^{\circledR}$ water. The stock solution was diluted to obtain standard solutions. The $\mathrm{pH}$ adjustments were made with either nitric acid or sodium hydroxide solutions.

\section{Beads preparation}

Sodium alginate salt from brown algae purchased from Fluka ${ }^{\circledR}$ (St. Louis, MO, USA) was used as hydrocolloidal gelling material. As fixing solution, a $\mathrm{CaCl}_{2}$ (PANREAC $\otimes$, Barcelona, Spain) solution was utilized. A $1 \%$ (w/v) sodium alginate solution was prepared by dissolving $1 \mathrm{~g}$ of sodium alginate into $100 \mathrm{~cm}^{3}$ distilled water at a temperature of about $65^{\circ} \mathrm{C}$. Then, the gel was allowed to cool down at room temperature and $2.0 \mathrm{~g}$ of leonardite were added to the gel with continuous stirring. Once the mixture was homogeneous, it was forced through a micropipette tip by a peristaltic pump. The resulting gel droplets were collected in a stirred reservoir containing $200 \mathrm{~cm}^{3}$ of a chemical fixing solution of $0.1 \mathrm{M} \mathrm{CaCl}_{2}$. The beads were allowed to harden in this solution for $24 \mathrm{~h}$. After this time, hard spherical beads containing $0.65 \mathrm{mg}$ (average) of leonardite were obtained. The beads were filtered and rinsed with distilled water to remove calcium chloride from the bead surface. They were then stored in distilled water until their use.

\section{Effect of $\mathrm{pH}$}

The effect of $\mathrm{pH}$ on the adsorption of $\mathrm{Cr}(\mathrm{III})$ by leonardite was studied with aqueous solutions of 5 and $10 \mathrm{ppm}$ metal concentration. The initial $\mathrm{pH}$ was adjusted to $2,3,4,5$, and 6 with nitric acid $0.1 \mathrm{~mol} \mathrm{dm}^{-3}$ or sodium hydroxide 
$0.1 \mathrm{~mol} \mathrm{dm}^{-3}$ solutions. Metal solutions without initial $\mathrm{pH}$ adjustment were also used. A dose of $200 \mathrm{mg}$ of leonardite were added to $200 \mathrm{~cm}^{3}$ of chromium solutions. A blank was prepared by adding $200 \mathrm{mg}$ of leonardite to $200 \mathrm{~cm}^{3}$ of Milli-Q water to verify whether the sorbent transferred chromium to water. Leonardite free blanks prepared at the same $\mathrm{pH}$ range were also investigated to check the possibility of chromium chemical precipitation. All mixtures were agitated with a magnetic stirrer (SBS) during $4 \mathrm{~h}$ at a constant temperature of $25{ }^{\circ} \mathrm{C}$. After that, aliquots were filtered through $0.45 \mu \mathrm{m}$ Millipore ${ }^{\circledR}$ cellulose filters and $\mathrm{Cr}$ (III) remaining concentrations were determined in the filtrate.

\section{Kinetic study}

In order to determine the equilibrium time and sorption mechanism, adsorption tests were conducted with solutions containing 5, 10, 20, 25, and $90 \mathrm{ppm}$ of $\mathrm{Cr}$ (III). A fixed dose of $500 \mathrm{mg}$ of leonardite was added to $500 \mathrm{~cm}^{3}$ of each solution. The mixtures were shaken at a constant temperature of $25{ }^{\circ} \mathrm{C}$. Samples were collected at various contact times $(0,15,30,60,180$, 240, 300, and $360 \mathrm{~min}$ ), filtered and analyzed.

\section{Sorption equilibrium}

The adsorption capacity of leonardite for Cr(III) was determined in solutions from 2 to $500 \mathrm{mg} \mathrm{L}^{-1}$ concentrations and keeping a constant amount of leonardite $\left(1 \mathrm{~g} \mathrm{~L}^{-1}\right)$. Experimental conditions used were the same as those described above at initial $\mathrm{pH}$ of 4-5. The same procedure was carried out with encapsulated leonardite. In this case, appropriate number of alginate beads were added to achieve the same leonardite dose of $1 \mathrm{~g} \mathrm{~L}^{-1}$.

\section{Chromium analysis}

The amount of $\mathrm{Cr}$ (III) in the solutions before and after the adsorption tests was determined by flame atomic absorption spectrophotometry (FAAS), using a Thermo Electron Corporation (SOLAAR S2 model) spectrophotometer with an acetylene-nitrous oxide flame. Wavelength was $359.9 \mathrm{~nm}$.

All experiments were performed twice. The repeatability of the results showed a variation coefficient lower than $5 \%$.

\section{Results and discussion}

\section{Effect of $\mathrm{pH}$}

$\mathrm{Cr}$ (III) sorption on leonardite was studied over the $\mathrm{pH}$ range 2-6. $\mathrm{Cr}$ (III) ions can exist in various chemical species in aqueous solutions. $\mathrm{Cr}$ (III) predominates at $\mathrm{pH}<3.0$. At the $\mathrm{pH}$ range $3.5^{-6}$, hydrolysis of aqueous $\mathrm{Cr}$ (III) ion yields trivalent chromium hydroxyl species such as $\mathrm{Cr}(\mathrm{OH})^{2+}$ and $\mathrm{Cr}(\mathrm{OH})_{2}{ }^{+}$. The formation of the only solid insoluble species $\mathrm{Cr}(\mathrm{OH})_{3}$ begins at $\mathrm{pH}>6$ (Mohan and Pittman 2006). Therefore, experiments were not conducted further than $\mathrm{pH}$ 6. Figure 1 shows the removal efficiency (\%) of $\mathrm{Cr}$ (III) ions versus initial $\mathrm{pH}$ for a fixed adsorbent dose of $1 \mathrm{~g} \mathrm{~L}^{-1}$ at initial metal concentrations of 5 and $10 \mathrm{ppm}$ of Cr(III). As it can be seen in the Fig. 1, the 
removal of $\mathrm{Cr}$ (III) ions by sorption on leonardite is $\mathrm{pH}$ dependent. Metal removal is enhanced with increasing $\mathrm{pH}$. From $\mathrm{pH} 4.0$ removal efficiencies were $100 \%$ for both concentrations. This is partly due to the fact that the distribution of metal chemical species in solution varies with the $\mathrm{pH}$, besides this parameter influences the net charge of the sorbent. Leonardite contains fulvic and humics acids which carry polar functional groups such as alcohols, aldehydes, carboxylic acids, ketones, and phenolic hydroxides (Olivella et al. 2011). These ones play important roles in ion exchanges and complexation during metal ions fixation from solution. The $\mathrm{pH}$ dependence of chromium suggests that metal ions are mainly adsorbed through ion exchange and complexation mechanisms. The sorption behavior can likely be ascribed to the effect of competitive binding between $\mathrm{Cr}$ (III) and hydrogen ions for the binding sites on the surface of the leonardite. At low $\mathrm{pH}$, an excess of hydrogen ions can compete effectively with $\mathrm{Cr}(\mathrm{III})$ for bonding sites, resulting in a lower level of $\mathrm{Cr}(\mathrm{III})$ uptake. At low $\mathrm{pH}$ (<2.0), functional oxidized groups (hydroxyl, carboxyl and phenol among others) of the coal are mainly protonated and therefore fewer groups for ion exchange can be available. Similar results have been reported by many authors in studies dealing with removal of different metal ions using several materials (Ram et al. 2004; Gode and Pehlivan 2005). Open image in new window

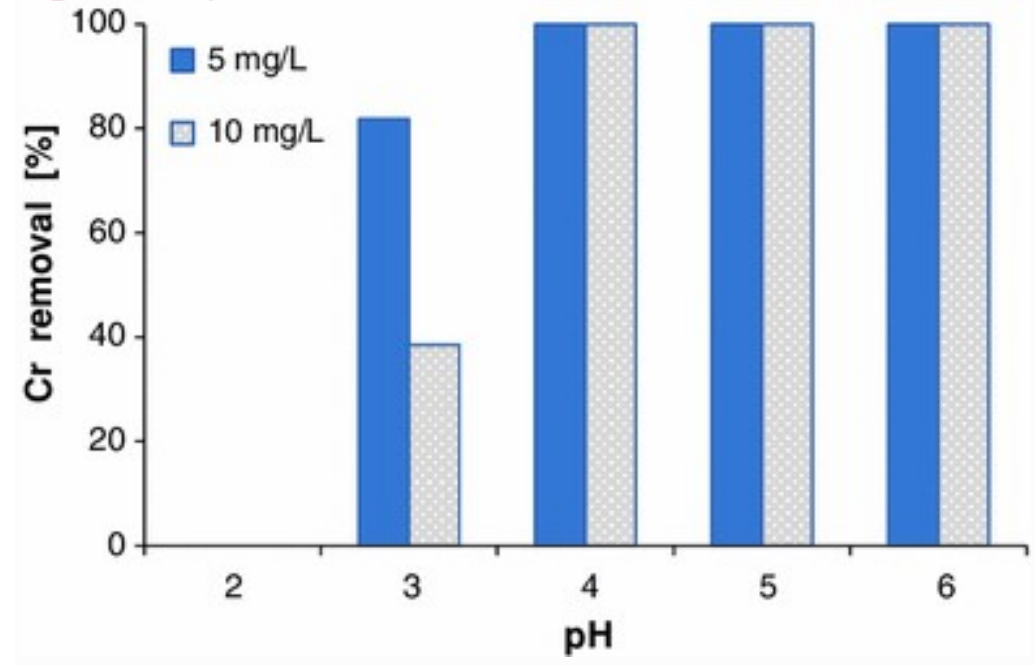

Fig. 1

Effect of $\mathrm{pH}$ on $\mathrm{Cr}(\mathrm{III})$ sorption onto leonardite

In order to discard the possible partial elimination of chromium due to precipitation as $\mathrm{Cr}(\mathrm{OH})_{3}$, leonardite free blanks adjusted at 2, 3, 4, 5, and $6 \mathrm{pH}$ values were also investigated. Results showed that at the interval range $2-5$ precipitation was irrelevant. However, at $\mathrm{pH} 6$ the removal due to precipitation was $21 \%$. That is why, the initial $\mathrm{pH}$ value used for the following experiments was fixed at the range $4-5$.

\section{Kinetic study}

Kinetics experiments of aqueous chromium sorption onto leonardite at the $\mathrm{Cr}$ (III) range concentration of $5^{-100 ~} \mathrm{mg} \mathrm{L}^{-1}$ were performed. The evolution of the $\mathrm{Cr}$ (III) concentration of chromium along time is shown in Fig. 2. As it can be seen, the decrease of chromium concentration in the aqueous phase is faster for lower chromium concentrations. For 5 and $10 \mathrm{ppm}$ leonardite removed $100 \%$ of chromium after 50 min, for 20 and $25 \mathrm{mg} \mathrm{L}^{-1}$ the total removal was 
$75 \%$ at the same time. Only $10 \%$ of chromium was extracted at 50 min for $90 \mathrm{ppm}$ concentration and total removal achieved at equilibrium time (300 min) was $40 \%$. This demonstrates that chromium removal by leonardite presents a clearly dependence on the initial chromium concentration.

Open image in new window

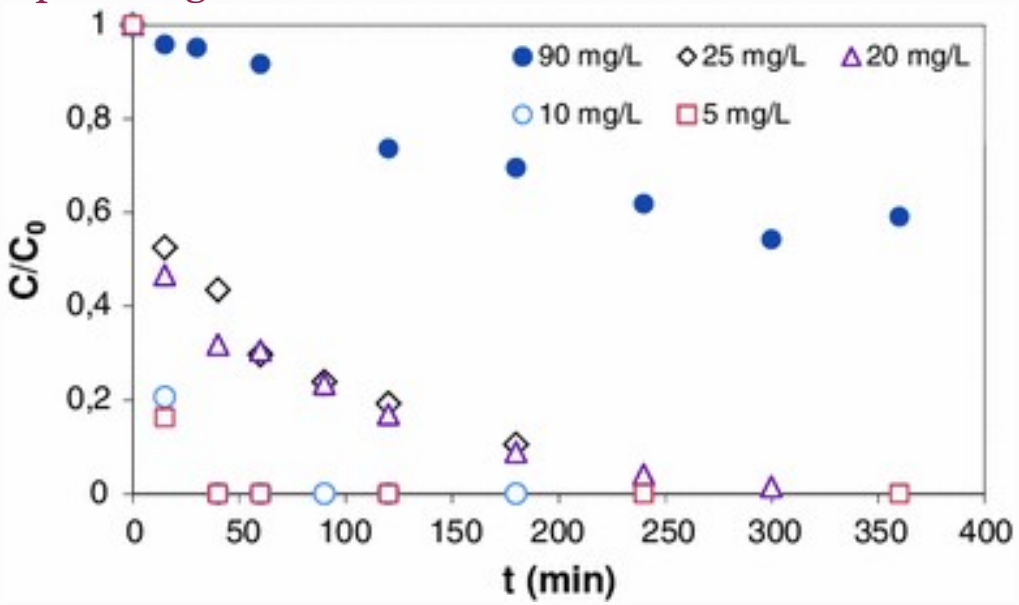

Fig. 2

Kinetic evolution of the Cr(III) removal onto leonardite, effect of the initial metal concentration

\section{Sorption kinetic models}

The aim was to characterize the kinetic sorption of chrome onto leonardite using three simplified models. The agreement between the experimental and the predicted data (in terms of deviation) determine which kinetic model describes properly the sorption process from a macroscopic point of view.

For this reason, data were collected under conditions of minimum film diffusion resistance. Accordingly, three simplified models were adopted to examine the sorption kinetics of chromium onto leonardite:

1)

The pseudo-first order model proposed by Lagergren (Tütem et al. 1998; Sarkar et al. 2003):

$\mathrm{dqtdt}=\mathrm{KS} 1(\mathrm{qe}-\mathrm{qt}) \mathrm{dqtdt}=\mathrm{KS} 1(\mathrm{qe}-\mathrm{qt})$

integrating Eq. 1 with conditions $q_{t}=0$ at $t=0 ; q_{t}=q_{t}$ at $t=t$ gives:

$\log (\mathrm{qe}-\mathrm{qt})=\operatorname{lnq} \mathrm{e}-\mathrm{KS} 1 \mathrm{t} 2,303 \log \quad(\mathrm{qe}-\mathrm{qt})=\ln \quad \mathrm{qe}-\mathrm{KS} 1 \mathrm{t} 2,303$

where $q_{e}$ and $q_{t}$ are the amount of solute adsorbed at equilibrium and time $t$, respectively; $K_{S_{1}}$ is the pseudo-first order rate constant which can be obtained from lineal regression analysis of Eq. 2 .

2)

The pseudo-second order equation based on the sorption equilibrium capacity in the form (Tütem et al. 1998; Vinod and Anirudhan 2003): $\mathrm{dqtdt}=\mathrm{Ks} 2(\mathrm{qe}-\mathrm{qt}) 2 \mathrm{dqtdt}=\mathrm{KS} 2(\mathrm{qe}-\mathrm{qt}) 2$ 
integrating Eq. $\underline{3}$ with conditions $q_{t}=0$ at $t=0 ; q_{t}=q_{t}$ at $t=t$ gives: tq $\mathrm{t}=1 \mathrm{Ks} 2 \mathrm{q} 2 \mathrm{e}+\mathrm{tq}$ etqt $=1 \mathrm{KS} 2 \mathrm{qe} 2+\mathrm{tqe}$

where $K_{S_{2}}$ is the pseudo-second order rate constant. Note that $K_{S_{2}}$ and 3) qecan be obtained from the lineal regression analysis of Eq. 4 .

The Elovich model, where the sorption process is described as a group of reaction mechanisms like diffusion in the dissolution, surface diffusion and activated catalytic surfaces, in the form:

$\mathrm{dqtdt}=\mathrm{aexp}(-\mathrm{bqt}) \mathrm{dqtdt}=\mathrm{aexp} \quad(-\mathrm{bqt})$

integrating equation $\underline{5}$ under conditions $q_{t}=0$ at $t=0 ; q_{t}$ at $t=t$ and subsequently rearranging, the integrated expression results in $\mathrm{q}=1 \mathrm{~b} \ln (\mathrm{ab})+1 \mathrm{~b} \ln (\mathrm{t}+\mathrm{to}) \mathrm{qt}=1 \mathrm{bln} \quad(\mathrm{ab})+1 \mathrm{bln} \quad(\mathrm{t}+\mathrm{to})$

where $t_{\mathrm{o}}$ is equal to $1 /(a b)$. If $a, b$ and $t \geq 1$, Eq. $\underline{6}$ can further be simplified as:

$q \mathrm{t}=1 \mathrm{~b} \ln (\mathrm{ab})+1 \mathrm{~b} \ln (\mathrm{t}) \mathrm{qt}=1 \mathrm{bln} \quad(\mathrm{ab})+1 \mathrm{bln}$

where $a$ and $b$ are the parameters of the Elovich rate equation obtained by linear regression analysis of Eq. $\underline{7}$ (Ho and Mckay 1998; Shubha et al. 2001).

Figure $\underline{3}$ shows the results of the chromium kinetics removal besides the linearized form of Eq. 2 (pseudo-first order), 4 (pseudo-second order) and 7 (Elovich). The rate constants $K_{S_{1}}$ and $K_{S_{2}}$, and the kinetic parameters of the Elovich equation model $(a, b)$ were calculated from the corresponding slope or intercept of each plot and they are collected on Table 2 .

Open image in new window

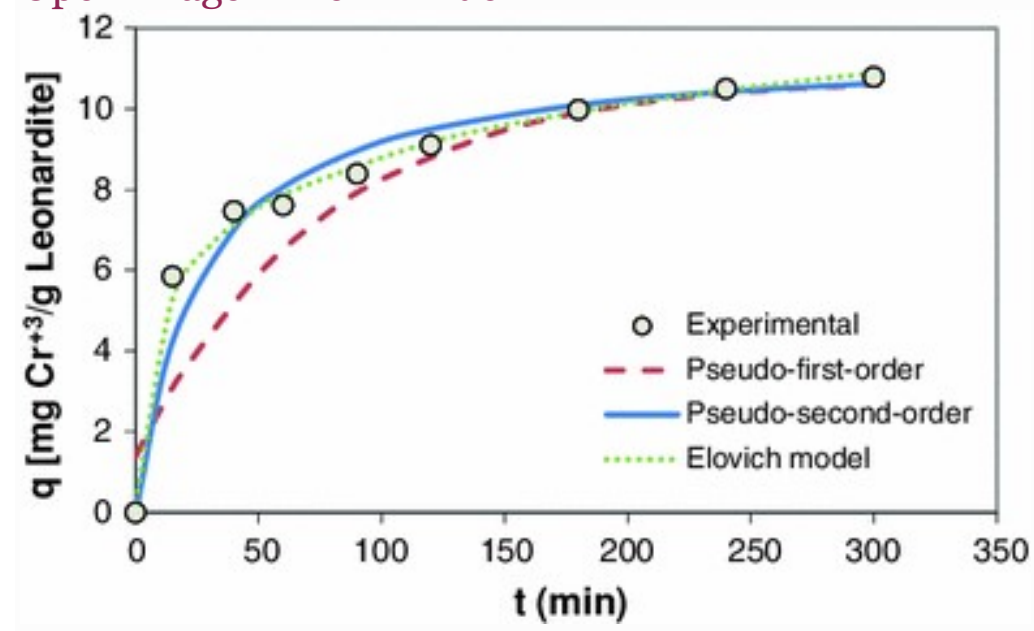

Fig. 3

Experimental and theoretical kinetic data obtained by the pseudo-second, pseudo-first and Elovich models for Cr(III) removal onto leonardite

Table 2 
Parameters of pseudo-first, pseudo-second order and Elovich models for Cr(III) removal onto Leonardite

\begin{tabular}{|c|c|c|}
\hline Model & Kinetic parameters & Value \\
\hline \multirow[t]{3}{*}{ Pseudo-first order } & $k_{\mathrm{s} 1}\left(\min ^{-1}\right)$ & $1.3 \times 10^{-2}$ \\
\hline & $q_{\mathrm{e}}\left(\mathrm{mg} \mathrm{dm}^{-3}\right)$ & 9.40 \\
\hline & $R^{2}$ & 0,96 \\
\hline \multirow[t]{3}{*}{ Pseudo-second order } & $k_{\mathrm{s} 2}\left(\mathrm{mg} \min ^{-1}\right)$ & $3.3 \times 10^{-3}$ \\
\hline & $q_{\mathrm{e}}\left(\mathrm{g} \mathrm{kg}^{-1}\right)$ & 11.55 \\
\hline & $R^{2}$ & 0,99 \\
\hline \multirow[t]{3}{*}{ Elovich } & $b\left(\mathrm{~g} \mathrm{mg}^{-1}\right)$ & 2.15 \\
\hline & $a\left(\mathrm{~g} \mathrm{mg}^{-1} \mathrm{~min}^{-1}\right)$ & 0.54 \\
\hline & $R^{2}$ & 0,99 \\
\hline
\end{tabular}

The $R^{2}$ coefficient was used as the guiding parameter to find out the kinetic models providing the better description of the chromium removal onto leonardite. This coefficient was calculated by means of the following equation: $\mathrm{R} 2=1-\left[\sum(\mathrm{ye}-\mathrm{yc}) 2 \sum(\mathrm{ye}-\mathrm{ym}) 2\right] \mathrm{R} 2=1-\left[\sum(\mathrm{ye}-\mathrm{yc}) 2 \sum(\mathrm{ye}-\mathrm{ym}) 2\right]$

where $y_{e}, y_{c}$, and $y_{m}$ are the experimental, predicted data, and the average of the experimental values, respectively. The higher value of $R$ 2 indicates the most suitable condition. The $R^{2}$ values are reported on Table $\underline{2}$.

As it can be seen in Fig. 3 , the pseudo-second order and the Elovich model fitted better the experimental data, with determination factor of 0.99 in both cases. In addition, the pseudo-first model also reported a quite good fit with $R^{2}=0.96$. The graphical analysis was also used to determine the loading equilibrium value $\left(q_{e}\right)$ from the intercept values of the pseudo-second order function. The calculated $q_{e}$ value reported a $2.5 \%$ deviation when compared with the experimental loading (11.85 $\mathrm{mg} \mathrm{g}^{-1}$ ). The good fit observed by the pseudo-second order kinetic model can indicate that the rate-limiting step may be chemical sorption or chemisorption involving valence forces through sharing or exchange of electrons between sorbent and sorbate (Ho and McKay 1999). Similar phenomenon has been observed in the biosorption of reactive dyes on biomass (Akzu and Tezer 2000; Aksu 2001).

Namasivayam and Höll (2004) reported the pseudo-second rate equation as the best fit to the experimental data for the Cr(III) removal from tannery wastewater by Dried Chinese Reed (Miscanthus sinensis). Similar results were reported by Hernáinz et al. (2008) using olive stone as sorbent to remove Cr(III) from aqueous solutions. 
Parameters reported by the Elovich model, (constants $a$ and $b$ ) represent the initial sorption rate and surface coverage, respectively (Ho and Mckay 1998). Anirudhan and Radhakrishnan (2007) studied the Cr(III) removal from water using a carboxylate-functionalized cation exchanger. The experimental loading was $11.57 \mathrm{mg} \mathrm{g}^{-1}$, and the best fit in their study was obtained by the pseudosecond order model $\left(q_{e}=11.57 \mathrm{mg} \mathrm{g}^{-1} ; K_{s 2}=5.4 \times 10^{-3} \mathrm{mg} \mathrm{min}^{-1}\right)$. The Elovich equation also reported good fit $\left(a=3.6 \mathrm{~g} \mathrm{mg}^{-1} ; b=0.56 \mathrm{~g} \mathrm{mg}^{-1} \mathrm{~min}^{-1}\right)$. These values are in agreement with those obtained in our study, indicating that kinetic performance of leonardite can be comparable to other sorbents.

\section{Kinetic controlling mechanism}

The sorption process occurs within the boundary layer around the sorbent and proceeds in the liquid-filled pores or along the walls of the pores of the sorbent. The latter two processes are called the external and internal mass transfer steps, respectively.

Heterogeneous sorption processes between solids and fluids can be explained through a number of sequential processes that determine the rate of the global mass transfer process: (a) the diffusion of the solute through the liquid film surrounding the particle (liquid film diffusion control); (b) the diffusion of the solute through the sorbent matrix of the sorbent (particle diffusion control); and (c) the chemical reaction with the functional groups attached to the matrix. One of these steps usually offers much greater resistance than the others and may, thus, be considered as the rate-limiting step of the process (Walker and Weartherley 1997). Kinetic models selected to describe the solute extraction data were two models widely used for fitting sorption and ion exchange data: the homogeneous particle diffusion model (HPDM) and the shell progressive model (SPM) or the shrinking core model (Helfferich 1962; Liberti and Passino 1977).

\section{The homogeneous particle diffusion model (HPDM)}

In this model, the extraction mechanism involves the diffusion of solute molecules from the aqueous solution into the sorbent phase through a number of possible resistances. The sorption of the solute molecule is rigorously described by Fick's equation. The controlled diffusion of solute molecules from an infinite volume of solution into sorbent particle was described by Boyd et al. (1947). As the diffusion rate controls sorption on spherical particles, the solution of the corresponding set of differential and algebraic equations gives:

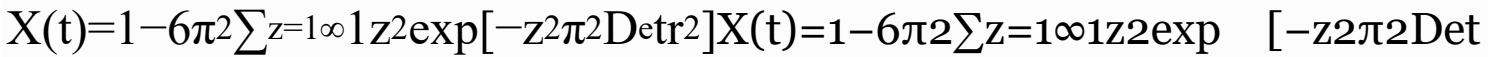
r2]

where $X(t)$ is the fractional attainment of equilibrium at time $t, D_{e}$ the effective diffusion coefficient of sorbates in the sorbent phase $\left(\mathrm{m}^{2} \mathrm{~s}^{-1}\right), \mathrm{r}$ the radius of the sorbent particle assumed to be spherical $(m)$, and $z$ is an integer number.

$X(t)$ values could be calculated using the following equation:

$X(\mathrm{t})=\mathrm{qtq} \mathrm{X}(\mathrm{t})=\mathrm{qtqe}$ 
where $q_{t}$ and $q_{e}$ are solute loading on the solid phase at time $t$ and when equilibrium is attained ( $\left.\mathrm{mg} \mathrm{g}^{-1}\right)$, respectively.

Vermeulen's (1953) approximation of the Eq. (9) fits the whole range $0<X(t)<1$, for sorption on spherical particles:

$X(t)=\left[1-\exp \left[-\pi 2 D^{2} \operatorname{etr} 2\right]\right] 1 / 2 X(t)=[1-\exp \quad[-\pi 2 \operatorname{De} 2 \operatorname{tr} 2]] 1 / 2$

This equation could be further simplified to cover most of the data points for calculating the effective particle diffusivity using the following expression:

$-\ln (1-\mathrm{X} 2(\mathrm{t}))=2 \mathrm{Kt}$ where $\mathrm{K}=\pi 2$ Der2-ln $\quad(1-\mathrm{X} 2(\mathrm{t}))=2 \mathrm{Kt}$ where $\mathrm{K}=\pi 2$ Der2

If liquid film diffusion controls the rate of sorption, the following analogous expression can be used:

$\mathrm{X}(\mathrm{t})=1-\exp [-3 \mathrm{DeCrCr}] \cdot \mathrm{X}(\mathrm{t})=1-\exp \quad[-3 \mathrm{DeCrCr}]$

or

$-\ln (1-\mathrm{X}(\mathrm{t}))=\mathrm{K}$ lit where $\mathrm{Kli}=3 \mathrm{DeCrCr}-\ln \quad(1-\mathrm{X}(\mathrm{t}))=$ Klit where

$\mathrm{Kli}=3 \mathrm{DeCrCr}$

\section{The shell progressive model (SPM)}

The shell progressive or unreacted shrinking core model is a mass transfer model in which the reaction starts at the particle surface, which forms a reacting zone and moves inward at a certain velocity.

In this case, the relationship between the sorption time and the sorption degree is given by the expressions below (Liberti and Passino 1977; Schmuckler and Goldstein 1977):

a)

When the process is controlled by the fluid film:

$\mathrm{X}(\mathrm{t})=3 \mathrm{CAoKmAasrCsotX}(\mathrm{t})=3 \mathrm{CAo} \quad \mathrm{KmAasrCsot}$

b)

When the process is controlled by the diffusion though the sorption layer:

$\left[3-3(1-X(t))^{2 / 3}-2 X(t)\right]=6$ DeCAoasr $2 \operatorname{Csot}[3-3(1-X(t)) 2 / 3-2 X(t)]=6 D$ e CAoasr2Csot

c)

When the process is controlled by the chemical reaction:

$$
[1-(1-\mathrm{X}(\mathrm{t})) 1 / 3]=\mathrm{ksCAort}[1-(1-\mathrm{X}(\mathrm{t})) 1 / 3]=\mathrm{ks} \quad \text { CAort }
$$


The experimental data were treated graphically and compared to all fractional attainment of equilibrium functions $(F(X)=f(t))$ defined previously for both models HPDM and SPM. Figure 4 shows the results of the chromium sorption kinetics fitted to the different equations for the HPDM (Eqs. 12, 14) and for the SPM (Eqs. 15-17) models (the initial Cr(III) concentration is $25 \mathrm{ppm}$ ).

Open image in new window
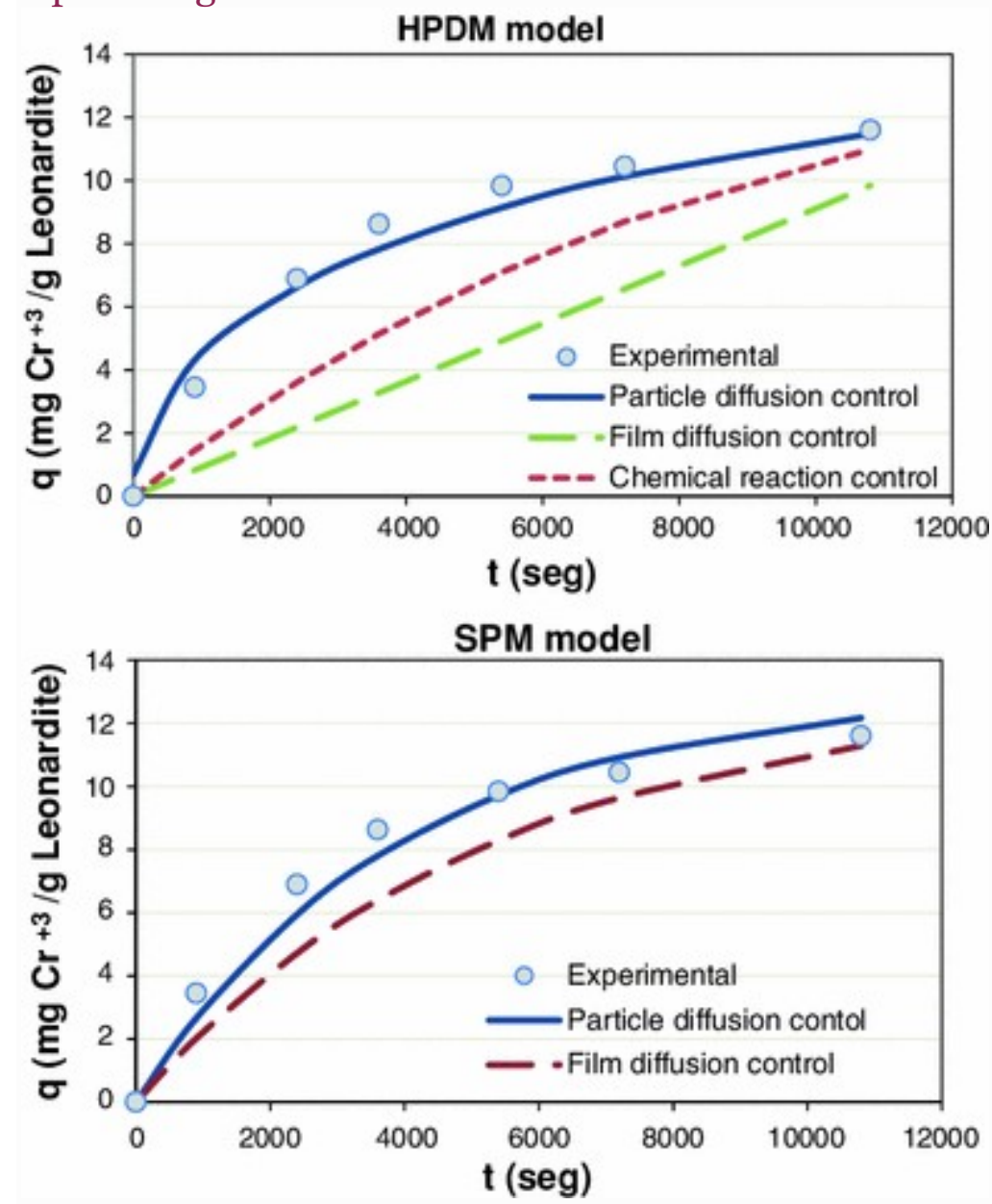

Fig. 4

Cr(III) kinetic data and theoretical curves obtained by the homogeneous particle diffusion (HPDM) and the shell progressive (SPM) models (initial $[\mathrm{Cr}(\mathrm{III})]=25 \mathrm{ppm})$

Kinetic experimental data fitted to HPDM and SPM models indicate that chemical reaction and film diffusion can be discarded as the sorptioncontrolling step due to the poor description of the experimental data as can be seen in Fig. 4 . The results of the linear regression analysis for the two models are summarized in Table 3 . The accuracy of model prediction was evaluated quantitatively based on the correlation coefficient $\left(R^{2}\right)$ and the average deviation (AD) which was calculated based on the sum of the differences between the experimental results and the theoretical data. The lower values of the $\mathrm{AD}$ were obtained for the particle diffusion control, indicating this mechanism as the rate-limiting diffusion control for the $\mathrm{Cr}$ (III) sorption onto Leonardite.

\section{Table 3}

Linear regression analysis of HPDM and SPM models for chromium sorption at different $\mathrm{Cr}(\mathrm{III})$ initial concentration onto leonardite 


\begin{tabular}{|c|c|c|c|c|c|c|c|}
\hline \multirow{3}{*}{$\begin{array}{l}{[\mathrm{Cr}(\mathrm{III})]} \\
\left(\mathrm{mg} \mathrm{L}^{-1}\right)\end{array}$} & \multicolumn{4}{|c|}{ HPDM } & \multicolumn{3}{|l|}{ SPM } \\
\hline & \multicolumn{2}{|c|}{$-\ln (1-\mathrm{X} 2)$} & \multicolumn{2}{|c|}{$-\ln (1-X)$} & \multicolumn{2}{|l|}{$\mathrm{X}$} & \multirow{2}{*}{$\begin{array}{l}{[3-3(1-\mathrm{X})} \\
\mathrm{AD} \\
\left(R^{2}\right)\end{array}$} \\
\hline & $\begin{array}{l}\mathrm{AD} \\
\left(R^{2}\right)\end{array}$ & $\mathrm{D}_{\mathrm{e}}$ & $\begin{array}{l}\mathrm{AD} \\
\left(R^{2}\right)\end{array}$ & $\mathrm{D}_{\mathrm{e}}$ & $\begin{array}{l}\mathrm{AD} \\
\left(R^{2}\right)\end{array}$ & $\mathrm{K}_{F}$ & \\
\hline 90 & $\begin{array}{l}23.4 \\
(0.95)\end{array}$ & $5.5 \times 10^{-15}$ & $\begin{array}{l}34.3 \\
(0.93)\end{array}$ & $9.5 \times 10^{-10}$ & $\begin{array}{l}26.0 \\
(0.92)\end{array}$ & $7.1 \times 10^{-10}$ & $\begin{array}{l}18.3 \\
(0.96)\end{array}$ \\
\hline 25 & $\begin{array}{l}9.5 \\
(0.99)\end{array}$ & $7.2 \times 10^{-14}$ & $\begin{array}{l}20.9 \\
(0.94)\end{array}$ & $6.3 \times 10^{-9}$ & $\begin{array}{l}51.6 \\
(0.70)\end{array}$ & $2.3 \times 10^{-9}$ & $\begin{array}{l}8.2 \\
(0.98)\end{array}$ \\
\hline 20 & $\begin{array}{l}14.5 \\
(0.98)\end{array}$ & $9.1 \times 10^{-14}$ & $\begin{array}{l}18.0 \\
(0.97)\end{array}$ & $6.9 \times 10^{-9}$ & $\begin{array}{l}55.1 \\
(0.67)\end{array}$ & $1.5 \times 10^{-9}$ & $\begin{array}{l}11.4 \\
(0.99)\end{array}$ \\
\hline
\end{tabular}

$D_{\text {e }}\left[\mathrm{m}^{2} \mathrm{~s}^{-1}\right] ; K_{S}, K_{F}\left[\mathrm{~m} \mathrm{~s}^{-1}\right]$

$m$ total number of experimental data, $A D$ Average deviation

$(\%)=\sum \mathrm{i}=1 \mathrm{mABS}\left(\mathrm{q}_{\text {expi- }}\right.$ qtheori $) / \mathrm{q}_{\text {expi }} \times 100 \mathrm{~m}=\sum \mathrm{i}=1 \mathrm{mABS}$ (qiexp-qitheor)/qiexp $\times 100 \mathrm{~m}$

The slope values were used to calculate the effective diffusion coefficients $\left(D_{e}\right)$ using Eqs. 14and 16. These diffusion coefficients calculated are, in fact, a measure of the mean inter-diffusion coefficient of the solute molecule involved in the sorption process. The effective diffusion coefficients reported in Table $\underline{3}$ were in the same order for both models. Only slight influence of the initial concentration of chromium was observed. This could be related to the fact that the sorbent has low surface area and, thus, less available sites for more solute molecules.

\section{Sorption equilibrium}

The effect of initial Cr(III) concentration on the uptake of this metal by leonardite was investigated by varying the initial concentration between 2 and $500 \mathrm{mg} \mathrm{L}^{-1}$. The tests were carried out for a contact time of four hours and a $1 \mathrm{~g} \mathrm{~L}^{-1}$ dose of leonardite. The specific metal uptake was obtained from a mass balance for the aqueous phase, using the following equation:

$\mathrm{q}=(\mathrm{Co}-\mathrm{Ce}) \mathrm{VWq}=(\mathrm{Co}-\mathrm{Ce}) \mathrm{VW}$

where $q\left(\mathrm{mg} \mathrm{g}^{-1}\right)$ is the amount of metal ion adsorbed per unit mass of leonardite, $\mathrm{C}_{\mathrm{e}}\left(\mathrm{mg} \mathrm{L}^{-1}\right)$ is the cation concentration at equilibrium, $C_{\mathrm{o}}\left(\mathrm{mg} \mathrm{L}^{-1}\right)$ is the initial metal concentration, $V(\mathrm{~L})$ is the solution volume and $W(\mathrm{~g})$ the adsorbent dry mass.

Figure $\underline{5}$ a shows the relationship between the different quantities of metal ions adsorbed per unit mass of leonardite and the equilibrium concentration of the Cr(III) ions. The isotherm exhibits a sharp slope in the lower concentration range of the solution phase. This indicates that leonardite has a high affinity for the metal studied and it is almost completely adsorbed from diluted solutions. At low concentrations, the ratio of available surface area and the initial number of metal ions is larger and, subsequently, the fractional adsorption is almost 
independent of initial concentrations. However, at higher concentrations, the number of available sites for adsorption is relatively fewer and hence the percentage of metal ions removal depends upon the initial concentration. Open image in new window
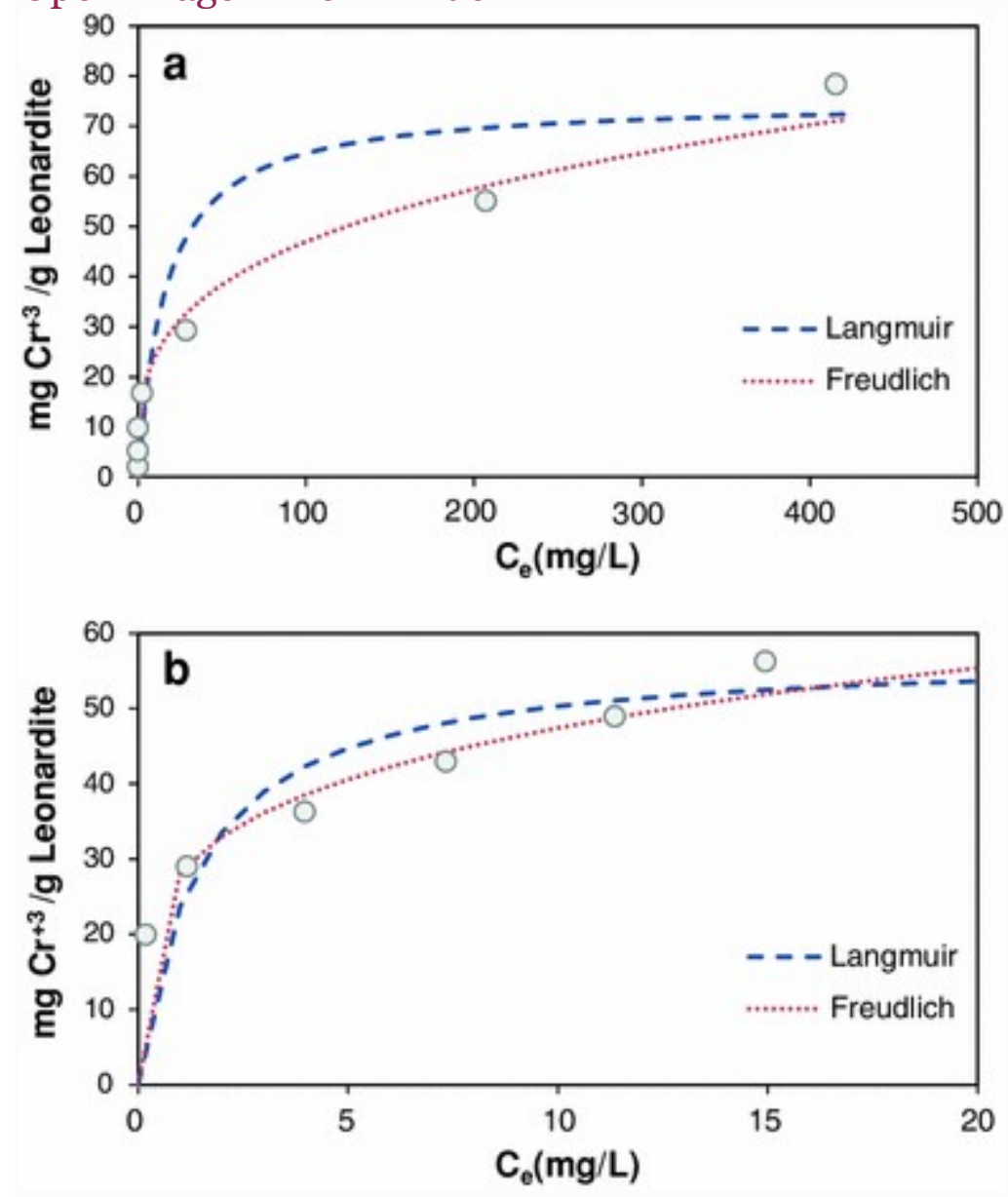

Fig. 5

Experimental and theoretical sorption data obtained by Langmuir and Freundlich models for Cr(III) removal onto $\mathbf{a}$ leonardite and $\mathbf{b}$ onto leonarditealginate beads

The experimental adsorption isotherm was fitted to the classic Langmuir and Freudlich models. The Langmuir adsorption isotherm (Eq. 19) describes sorption on homogeneous surface sorbents, assuming that all the adsorption sites have equal adsorbate affinity and that adsorption at one site does not affect adsorption at an adjacent site. At saturation, a monolayer is formed and $q_{\text {max }}$ is the monolayer adsorption capacity $\left(\mathrm{mg} \mathrm{g}^{-1}\right)$ and $K_{L}$ the equilibrium constant. However, heavy metal sorption on heterogeneous sorbents has been also interpreted by the aid of the Langmuir isotherm on various occasions in the environmental literature (Mohan and Pittman 2006). $\mathrm{q}=\mathrm{qmaxKLCe} 1+\mathrm{bCeq}=\mathrm{qmaxKLCe} 1+\mathrm{bCe}$

Freundlich model is an empirical Eq. 20 that describes the equilibrium sorption on a heterogeneous surface and does not assume a monolayer capacity. The constant $\mathrm{n}$ is an empirical parameter that varies with the degree of heterogeneity and $K_{F}$ is related to the maximum adsorption capacity. $\mathrm{q}=\mathrm{KFC} 1 / \mathrm{neq}=\mathrm{KFCe} 1 / \mathrm{n}$ 
The Langmuir parameters ( $q_{\text {max }}$ and $b$ ) and Freundlich parameters $\left(K_{F}\right.$ and $n$ ) were calculated by linearization of the Eqs. 19 and 20 , respectively. Calculated values for these parameters are shown in Table 4 together with the correlation coefficients. The correlation coefficients $\left(r^{2}\right)$ values indicate that, in general, experimental data were better fitted to the Freundlich model.

\section{Table 4}

Langmuir and Freundlich constants from Cr(III) sorption onto leonardite and leonardite alginate beads

\begin{tabular}{|l|l|llll|}
\hline & & \multicolumn{2}{|c}{ Langmuir } & \multicolumn{2}{l|}{ Freundlich } \\
\hline & & $q_{\max }\left(\mathrm{mg} \mathrm{g}^{-1}\right)$ & $K_{L}\left(\mathrm{~L} \mathrm{mg}^{-1}\right)$ & $K_{F}\left(\mathrm{~L} \mathrm{~g}^{-1}\right)$ & $n$ \\
\hline Leonardite & Constants & 75.2 & 0.061 & 12.33 & 3.4 \\
\cline { 2 - 6 } & $r^{2}$ & 0.961 & & 0.980 & \\
\hline Leonardite alginate beads & Constants & 57.47 & 0.701 & 28.25 & 4.4 \\
\cline { 2 - 6 } & $r^{2}$ & 0.973 & & 0.983 & \\
\hline
\end{tabular}

Based on the literature revised, it is evident that these models, originally developed for gas adsorption on surfaces, could be employed for metal adsorption on complex surfaces. However, as stated by Volesky (2004) the application of these models should be limited to the mathematical representation of the data and the mechanistic inferences should be drawn very carefully.

Although Langmuir model sheds no light on the mechanistic aspects of chromium sorption, it provides information on uptake capabilities and it has practical utility for representing the limiting sorption capacities for the sorbents.

According to the Langmuir equation, the maximum adsorption capacity for $\mathrm{Cr}$ (III) $\left(q_{\max }\right)$ for leonardite was $75.19 \mathrm{mg} \mathrm{g}^{-1}$. This value is greater than those reported for chromium adsorption in the literature (Gode and Pehlivan 2005; Lyubchik et al. 2004; Alvarez-Ayuso et al. 2007; Mohan and Pittman 2006) and comparable to those of the highest adsorption capacities reported McKay et al. (1989), (82 $\left.\mathrm{mg} \mathrm{g}^{-1}\right)$ and Kertman et al. (1993) $\left(76 \mathrm{mg} \mathrm{g}^{-1}\right)$.

\section{Sorption studies with LA-beads}

The equilibrium isotherms were determined by contacting the beads with solutions of different initial $\mathrm{Cr}$ (III) concentrations within the range 20$500 \mathrm{mg} \mathrm{L}^{-1}$. The initial solutions $\mathrm{pH}$ was adjusted at $\mathrm{pH}=5$. In order to compare with the sorption experiments with raw leonardite, the number of beads used was equivalent to a concentration of $1 \mathrm{~g}$ leonardite $\mathrm{L}^{-1}$. 
After 2 hours of contact, LA-beads were partially destroyed at chromium initial concentrations above $100 \mathrm{ppm}$. For lower chromium concentrations, the beads remained stable and the results obtained are presented in Fig. $\underline{5} \mathrm{~b}$. According to the Langmuir equation (Table $\underline{4}$ ), the maximum adsorption capacity for $\mathrm{Cr}$ (III) $\left(q_{\max }\right)$ was $57.47 \mathrm{mg} \mathrm{g}^{-1}$, slightly lower than that found for the untreated material.

Concentrated $\mathrm{Cr}(\mathrm{III})$ solutions (above $100 \mathrm{mg} \mathrm{L}^{-1}$ ) exhibited low initial $\mathrm{pH}$ values $(<3.5)$ due to $\mathrm{Cr}(\mathrm{III})$ ion acidic characteristics. In order to increase solutions $\mathrm{pH}$ to achieve an optimal $\mathrm{pH}$ range between 4 and 5 (as described in the $\mathrm{pH}$ results section of this study), $\mathrm{Cr}$ (III) solutions were adjusted with sodium hydroxide, being the added amounts higher for the higher Cr(III) concentrations. Therefore, breakage of beads observed in solutions of higher $\mathrm{Cr}$ (III) concentrations could be due to substitution of the calcium ions from Caalginate beads by sodium ions, causing the beads destabilization. Although in the last years considerable research has focused on the use of calcium alginate beads as immobilization method for low-cost sorbents (Pandey et al. 2003, Fiol et al. 2004; Escudero et al. 2006; Lai et al. 2008), in none of these works the beads destabilization was described. This may be due to many of these studies were carried out under conditions in which $\mathrm{pH}$ adjustment was not required because: i) cations studied are much less acidic than chromium ii) adsorption was performed with anionic forms of chromium (VI) at acid pH with good results or iii) the concentration of chromium (III) in the solutions was less than $100 \mathrm{mg} \mathrm{L}^{-1}$.

\section{Conclusions}

Chromium (III) sorption onto leonardite is $\mathrm{pH}$ dependent and the optimum adsorption was observed in the $\mathrm{pH}$ range $4-5$.

Kinetic test showed faster reduction of the initial concentration for lower chromium initial concentrations. The loading equilibrium value and the determination coefficient confirmed that the pseudo-second-order model describes properly the experimental sorption data for chromium removal onto leonardite.

Results obtained on the kinetics sorption of chromium from aqueous solutions indicated that the rate determining step of the solute extraction is the sorbentphase diffusion. Two well-established models, HPDM and SPM allowed the calculation of effective or mean inter-diffusion coefficient which provides an insight into the diffusion mechanism and a parameter for subsequent design calculations.

The equilibrium data were adjusted to sorption isotherm models (Langmuir and Freundlich). Both isotherms provided a suitable description of chromium sorption on leonardite and the maximum adsorption capacity was found to be $75.2 \mathrm{mg} \mathrm{Cr}$ (III) $\mathrm{g}^{-1}$. Adsorption capacity of LA-beads was found to be slightly lower than non-encapsulated leonardite. It should be noted that $\mathrm{Cr}$ (III) sorption onto LA-beads from solutions with high $\mathrm{Cr}(\mathrm{III})$ concentration is affected by LA-beads stability. 


\section{Notes}

\section{Acknowledgments}

The Spanish government (MEC) provided financial support through the project CICYT CTQ2008-06842-C02-02.

\section{References}

1. Aksu Z (2001) Biosorption of reactive dyes by dried activated sludge: equilibrium and kinetic modelling. Biochem Eng 7:79-84CrossRefGoogle $\underline{\text { Scholar }}$

2. Akzu Z, Tezer S (2000) Equilibrium and kinetic modelling of biosorption of Remazol Black B by Rhizopus arrhizus in a batch system: effect of temperature. Process Biochem 36:431-439 CrossRefGoogle Scholar

3. Alvarez-Ayuso E, García-Sanchez A, Querol X (2007) Adsorption of Cr(VI) from synthetic solutions and electroplating wastewaters on amorphous aluminium oxide. J Hazard Mater 142:191-198 CrossRefGoogle Scholar

4. Anirudhan TS, Radhakrishnan PG (2007) Chromium(III) removal from water and wastewater using a carboxylate-functionalized cation exchanger prepared from a lignocellulosic residue. J Colloid Interfaces Sci 316:268276 CrossRefGoogle Scholar

5. Boyd E, Adamson AW, Meyers LS (1947) J Am Chem Soc 69:2849 CrossRefGoogle Scholar

6. Das Ch, Patel P, De Sirshendu, DasGupta S (2006) Treatment of tanning effluent using nanofiltration followed by reverse osmosis. Sep Purif Technol 50:291-299 CrossRefGoogle Scholar

7. Di Natale F, Lancia A, Molino A, Musmarra D (2007) Removal of chromium ions form aqueous solutions by adsorption on activated carbon and char. J Hazard Mater 145:381-390 CrossRefGoogle Scholar

8. Directive 2008/105/EC of the European Parliament and of the Council of 16 December 2008 on environmental quality standards in the field of water policy, amending and subsequently repealing Council Directives 82/176/EEC, 83/513/EEC, 84/156/EEC, 84/491/EEC, 86/280/EEC and amending Directive 2000/60/EC of the European Parliament and of the CouncilGoogle Scholar

9. Escudero C, Fiol N, Villaescusa I (2006) Chromium sorption on grape stalks encapsulated in calcium alginate beads. Environ Chem Lett 4:239242CrossRefGoogle Scholar

10. Esmaeili A, Mesdaghi Nia A, Vazirinejad R (2005) Chromium (III) removal and recovery from tannery wastewater by precipitation processes. Am J Appl Sci 10:1471-1473Google Scholar 
11. Fendorf SE (1995) Surface reactions of chromium in soils and waters. Geoderma 67:55-67CrossRefGoogle Scholar

12. Fiol N, Poch J, Villaescusa I (2004) Chromium (VI) uptake by grape stalks wastes encapsulated in calcium alginate beads: equilibrium and kinetics studies. Chem Speciat Bioavailab 16:25-33CrossRefGoogle Scholar

13. Fiol N, Escudero C, Villaescusa I (2008) Chromium sorption and Cr(VI) reduction to $\mathrm{Cr}$ (III) by grape stalks and yohimbe bark. Bioresour Technol 99:5030-5036CrossRefGoogle Scholar

14. Gode F, Pehlivan E (2005) Removal of Cr(VI) from aqueous solution by two Lewatit-anion exchange resins. J Hazard Mater 119:175182CrossRefGoogle Scholar

15. González FJ, Martín F, del Rio JC, Fründ R (1992) Structural characteristics and geochemical significance of humic acids isolated from three Spanish lignite deposits. Sci Total Environ 117-118:335343CrossRefGoogle Scholar

16. Helfferich F (1962) Ion exchange. Mc Graw-Hill, New YorkGoogle Scholar

17. Hernáinz F, Calero M, Blázquez G, Martín-Lara MA, Tenorio G (2008) Comparative study of the biosorption of cadmium(II), chromium(III), and lead(II) by Olive Stone. Environ Prog 27:469-478 CrossRefGoogle Scholar

18. Ho YS, McKay G (1998) Sorption of dye from aqueous solution by peat. Chem Eng J 70:115-124CrossRefGoogle Scholar

19. Ho YS, McKay G (1999) Pseudo-second order model for sorption processes. Process Biochem 34:451-465 CrossRefGoogle Scholar

20.Kertman SV, Kertman GM, Chibrikova ZH (1993) Peat as heavy-metal adsorbent. J Appl Chem 66:465-466Google Scholar

21. Lai YL, Annadurai G, Huang FC, Lee JF (2008) Biosorption of Zn(II) on the different Ca-alginate beads from aqueous solution. Bioresour Technol 99:6480-6487CrossRefGoogle Scholar

22. Lalvani SB, Wiltowski T, Bner AH, Weston A, Mandich N (1998) Removal of hexavalent chromium and metal cations by a selective and novel. Carbon 36:1219-1226CrossRefGoogle Scholar

23. Lao C, Zeledon Z, Gamisans X, Solé M (2005) Sorption of Cd(II) and $\mathrm{Pb}$ (II) from aqueous solutions by a low-rank coal (leonardite). Sep Purif Technol 45:79-85 CrossRefGoogle Scholar

24. Lazaridis NK, Charalambous Ch (2005) Sorptive removal of trivalent and hexavalent chromium from binary aqueous solutions by composite alginate-goethite beads. Water Res 39:4385-4396rossRefGoogle Scholar 
25. Liberti L, Passino R (1977) Chapter 3. In: Marinsky JA, Marcus Y (eds) Ion Exchange and Solvent Extraction, vol 7. Marcel Dekker, NewYorkGoogle $\underline{\text { Scholar }}$

26. Liguori B, Cassese A, Colella C (2006) Safe immobilization of Cr(III) in heat-treated zeolite tuff compacts. J Hazard Mater 137:12061210CrossRefGoogle Scholar

27. Lyubchik SI, Lyubchik A, Galushko OL, Vital J, Fonseca IM, Lyubchik SB, Tikhonova LP (2004) Kinetics and thermodynamics of the Cr(III) adsorption on the activated carbon from co-mingled wastes. Colloids Surf A Physicochem Eng Aspects 242:151-158 CrossRefGoogle Scholar

28. McKay G, Blair HS, Findon A (1989) Equilibrium studies for the sorption of metal ions onto chitosan. Indian J Chem 28:356-36o Google Scholar

29. Mohan D, Pittman CU Jr (2006) Activated carbons and low cost adsorbents for remediation of tri- and hexavalent chromium from water. $\mathrm{J}$ Hazard Mater 137:762-811 CrossRefGoogle Scholar

30.Mouedhen G, Feki M, De Petris-Wery M, Ayedi HF (2009) Electrochemical removal of $\mathrm{Cr}(\mathrm{VI})$ from aqueous media using iron and aluminum as electrode materials: towards a better understanding of the involved phenomena. J Hazard Mater 168:983-991rossRefGoogle Scholar

31. Mousavi SA, Mirbagheri SA, Mohammadi T (2009) Using reverse osmosis membrane for chromium removal from aqueous solution. World Acad Sci Eng Technol 57:348-352Google Scholar

32. Namasivayam C, Höll WH (2004) Chromium(III) removal in tannery waste waters using Chinese Reed (Miscanthus Sinensis), a fast growing plant. Holz als Roh- und Werkstoff 62:74-80 $\underline{\text { Cross RefGoogle Scholar }}$

33. Olivella MA, Solé M, Gorchs R, Lao C, De Las Heras FXC (2011) Geochemical characterization of a Spanish leonardite coal. Arch Min Sci 56(4):789-804 Google Scholar

34. Pandey AK, Pandey SD, Misra V, Devi S (2003) Role of humic acid entrapped calcium alginate beads in removal of heavy metals. J Hazard Mater 98:177-181 $\underline{\text { CrossRefGoogle Scholar }}$

35. Ram N, Bajaj M, Sharma N, Gupta A (2004) Adsorption of Cr(VI) on activated rice husk carbon and activated alumina. Bioresour Technol 91:305-307CrossRefGoogle Scholar

36. Rana P, Mohan N, Rajagopal C (2004) Electrochemical removal of chromium from wastewater by using carbon aerogel electrodes. Water Res 38:2811-2820 CrossRefGoogle Scholar

37. Rengaraj S, Yeon K-H, Moon S-H (2001) Removal of chromium from water and wastewater by ion exchange resins. J Hazard Mater 87:273287CrossRefGoogle Scholar 
38. Sarkar M, Acharya PK, Bhattacharya B (2003) Modeling the adsorption kinetics of some priority organic pollutants in water from diffusion and activation energy parameters. J Colloid Interfaces Sci 266:2832 CrossRefGoogle Scholar

39. Schmuckler G, Goldstein S (1977) Chapter 1. In: Marinsky JA, Marcus Y (eds) Ion Exchange and Solvent Extraction, Vol 7. Marcel Dekker, New YorkGoogle Scholar

40.Shubha KP, Raji C, Anirudhan TS (2001) Immobilization of heavy metals from aqueous solutions using polyacrylamide grafted hydrous tin (IV) oxide gel having carboxylate functional groups. Water Res 35:300310CrossRefGoogle Scholar

41. Solé M, Casas JM, Lao C (2003) Removal of $\mathrm{Zn}$ from aqueous solutions by low-rank coal. Water Air Soil Pollut 144:57-65CrossRefGoogle Scholar

42.Tan KH (1996) Soil sampling, preparation and analysis. Marcel Dekker, New YorkGoogle Scholar

43. Tütem E, Apak R, Ünal ÇF (1998) Adsorptive removal of chlorophenols from water by bituminous shale. Water Res 32:2315-2324CrossRefGoogle $\underline{\text { Scholar }}$

44. Vasudevan S, Lakshmi J, Vanathi R (2010) Electrochemical coagulation for chromium removal: process optimization, kinetics, isotherms and sludge characterization clean. Clean Soil Air Water 38:9-16 $\underline{\text { Scholar }}$

45. Vermeulen T (1953) Theory of irreversible and constant-pattern solid diffusion. Ind Eng Chem 45:1664-1670 CrossRefGoogle Scholar

46.Vinod VP, Anirudhan TS (2003) Adsorption behaviour of basic dyes on the humic acid immobilized pillared clay. Water Air Soil Pollut 150:193217CrossRefGoogle Scholar

47. Volesky B (2004) Sorption and biosorption. BV-sorbex Inc, St LambertGoogle Scholar

48. Walker GM, Weartherley LR (1997) Adsorption of acid dyes on to granular activated carbon in fixed beds. Water Res 31:2093-2101CrossRefGoogle $\underline{\text { Scholar }}$

49.Zeledón Z, Lao C, Sole M (2005) Nickel and copper removal from aqueous solution by an immature coal (leonardite): effect of $\mathrm{pH}$, contact time and water hardness. J Chem Technol Biotechnol 8o:649-656CrossRefGoogle $\underline{\text { Scholar }}$

50.Zeledón Z, Lao C, de Las Heras FXC, Sole M (2007) Removal of PAHs from water using an immature coal (leonardite). Chemosphere 67:505512CrossRefGoogle Scholar 